\title{
A Simplified Anaerobic Bioreactor for the Treatment of Selenium-Laden Discharges from Non-acidic, End-Pit Lakes
}

\author{
Andreas Luek • Curtis Brock • David J. Rowan • \\ Joseph B. Rasmussen
}

Received: 4 November 2013/ Accepted: 15 July 2014/Published online: 21 October 2014

(C) The Author(s) 2014. This article is published with open access at Springerlink.com

\begin{abstract}
Selenium (Se) contamination of aquatic resources and its mitigation is of global concern. Anaerobic bioreactors are the most promising method for treating Seladen water in end-pit lakes resulting from intensive coal mining and waste rock leachate in the Canadian Rockies. This study assessed the suitability of a bioreactor system to treat non-acidic, coal mine effluent containing $85 \mu \mathrm{g} / \mathrm{L}$ of $\mathrm{Se}$, near Grande Cache, AB, Canada, while making the system as cheap as possible using locally available materials. We successfully used a sediment inoculum from the same end-pit lake as the effluent source to obtain sulfur/Sereducing bacteria and mixed the inoculum with mulch, manure, gravel, limestone, and bone meal to comprise the 'active substrate' for the bioreactors. The anaerobic bioreactors reduced $>95 \%$ of the total Se in the inflow water with a flow rate of $\approx 0.2 \mathrm{~m}^{3} / \mathrm{h}$. Se removal was not related to water temperature, which declined from 17 to $\approx 2{ }^{\circ} \mathrm{C}$ in November, suggesting water can be treated regardless of temperature. The use of manure as a bacterial carbon/ nitrogen source introduced Escherichia coli into the
\end{abstract}

\author{
A. Luek $(\square)$. J. B. Rasmussen \\ Department of Biological Sciences, University of Lethbridge, \\ 4401 University Dr, Lethbridge, AB T1K 3M4, Canada \\ e-mail: andreas.luek@gmail.com \\ J. B. Rasmussen \\ e-mail: joseph.rasmussen@uleth.ca \\ C. Brock \\ Alberta Environment, 250 Diamond Ave, Spruce Grove, \\ AB T7X 4C7, Canada \\ e-mail: curtis.brock@gov.ab.ca \\ D. J. Rowan \\ Atomic Energy of Canada Ltd (AECL), Chalk River, \\ ON K0J 1J0, Canada \\ e-mail: rowand@aecl.ca
}

downstream environment, but after a short elevated concentration, the abundance of $E$. coli dropped below water quality guidelines. We were able to show that successful Se reduction can be achieved using an anaerobic bioreactor design and locally available material. This design kept the building and maintenance price lower than previous reactors, making the approach promising for larger scale applications and making bioreactors a more cost accessible remediation technology for non-acidic end-pit lakes.

Keywords Bioremediation $\cdot$ Mining effluent $\cdot$ Non-acidic pit lakes $\cdot$ Selenium reduction $\cdot$ Water treatment

\section{Introduction}

Selenium (Se) is an important micronutrient for all living organisms (Winkel et al. 2011), yet a slight increase in concentration makes it toxic to many mammals, birds, and fish (Lemly 1993a). In aquatic communities, the most prevalent effects of Se contamination are teratogenic deformities (Conley et al. 2009; Debruyn and Chapman 2007; Hamilton 2004) and a lack of reproductive success (Deforest et al. 2011). These effects are of particular concern in fish, which are sensitive to small increases in Se concentrations (Janz 2011; Lemly 2002). In fish, Se causes severe head, mouth, fin, and spinal deformities (Lemly 1993b) and has been linked to the extirpation of several fish populations (Janz 2011). Se is a contaminant of global concern and discharge of Se into freshwater ecosystems must be controlled.

Common sources of Se contamination are fly ash from coal power plants (Lemly 1997; Ruhl et al. 2012), leachate from irrigated seleniferous soils, including agricultural lands of the western USA (Banuelos et al. 2002; Wu 2004), 
and rock drainage from open pit mines, including those in the American and Canadian Rockies, the Appalachian Mountains, and their foothills (Griffith et al. 2012; Kelly and Janz 2009). In Canada, for example, the larger rivers draining the eastern slopes of the Rockies, i.e. the Elk, McLeod, and Athabasca Rivers, are increasingly affected by Se discharged into their tributaries by mining operations in their headwaters (Dessouki and Ryan 2010; Orr et al. 2006). The amount of Se in the Elk River has increased continuously since the 1980 s, presently averaging over $5 \mu \mathrm{g} / \mathrm{L}$ (Dessouki and Ryan 2010). At a base flow of approximately $50 \mathrm{~m}^{3} / \mathrm{s}$, this means $21.6 \mathrm{~kg}$ of Se/day moving down the Elk River alone (data used from Dessouki and Ryan 2010). On this scale, the amount of Se released downstream is basically untreatable.

Clearly, effective, long-term, cost efficient methods are required to treat large volumes of Se-laden discharge. Thus far, research has focused on three broad approaches to remove Se from wastewater: (1) physical methods including nanofiltration or reverse osmosis (Kharaka et al. 1996), (2) direct chemical treatments using zero-valent iron or ferrous hydroxides (Frankenberger et al. 2004; Zhang et al. 2005), and (3) various biological treatment options. Biological treatments range from Se extraction or precipitation using artificial or constructed wetlands (Thompson et al. 2003; Zhang and Frankenberger 2003), to phytoremediation using bio-engineered plants (Banuelos et al. 2002; Berken et al. 2002; Terry et al. 2003), to bacterial reduction in bioreactors or sludge reactors (Fujita et al. 2002; Lenz et al. 2008; Macy et al. 1993). The anaerobic sulfatereducing bacteria cultured inside bioreactors are efficient at reducing aquatic selenites and selenates (Se oxyanions) to elemental Se (Cantafio et al. 1996; Hockin and Gadd 2006; Macy et al. 1993). These bacteria preferentially substitute sulfates with Se oxyanions as electron sources due to the chemical similarity of Se to sulfur and the higher energy potential of Se (Steinberg et al. 1992). While several treatment options reduce selenates and selenites to elemental Se using bacteria, this approach using bioreactors has thus far been the most successful at removing Se from wastewater (Lenz and Lens 2009).

While several experimental (small-scale) bioreactors have tested the potential of sulfate-reducing bacterial communities to treat Se-laden effluents (Hockin and Gadd 2006; Lenz et al. 2008; Zhang and Frankenberger 2006), a number of lab-sized approaches tested the performance of specific bacteria (Hunter and Manter 2009; Oremland et al. 1994). Most of these experiments were conducted under very controlled environments with lactate or acetate as the carbon source and were designed for warm to temperate climates. Furthermore, the designed reactors were elaborate constructs with high building and maintenance costs. For one of these test reactors, Cantafio et al. (1996) estimated the price of the acetate feed at US $\$ 0.62 / \mathrm{m}^{3}$ of water treated. Therefore, to treat one effluent source with a low discharge rate of $0.5 \mathrm{~m}^{3} / \mathrm{s}$, it would cost nearly US $\$ 1$ million/year for the acetate feed alone. To treat the Elk River at $50 \mathrm{~m}^{3} / \mathrm{s}$ (Dessouki and Ryan 2010), it would cost 10 times that amount (US $\$ 10$ million/year) just for the carbon source. Realistically, treatment must be implemented at the discharge source, e.g. mine outflows and small tributaries, to reduce the volume of water requiring treatment. Various large-scale reactors have been built and tested (Gusek et al. 2008; Rutkowski et al. 2013) but challenges remain for efficient treatment and long-term feasibility (Lenz and Lens 2009).

Anaerobic bioreactors were recently deemed the most promising method for the passive treatment of Se-laden effluent from intensive coal mining in the Canadian Rockies in Alberta, Canada (Alberta Environment 2006). Of particular concern for remediation are end-pit lakes, drainage collection pools that remain after open-pit mining has ceased, which have high water concentrations of Se and represent a major Se contamination source for Albertan rivers and their watersheds. The current study assessed the suitability of a bioreactor system to field-treat Se-laden coal mine effluent from a non-acidic end-pit lake, near Grade Cache, in west-central Alberta, while making the reactor as cheap as possible. To reduce the cost, the bioreactor system was of simple design and used, wherever possible, locally available materials, including a sediment inoculum (bacterial source) from the same end-pit mine lake used as the effluent source. We identified three key features needed for successful Se reduction in an anaerobic bioreactor and evaluated the performance of our model reactor along them: first, the required environment within the reactor is anoxic; second, the bacterial community needs to be capable of reducing selenites and selenates to elemental Se and; third, the substrate of the reactor needs to be able to support the growth of the required bacterial community. This study was a proof-of-concept for reclamation of Se-laden, coal mine effluent and provides important considerations for future full-scale treatment designs using end-pit lakes.

\section{Methods}

\section{Field Site Description}

The bioreactor system was built on the property of Grande Cache Coal Inc., approximately $20 \mathrm{~km}$ north of Grande Cache, $\mathrm{AB}$, and about $440 \mathrm{~km}$ west of Edmonton, $\mathrm{AB}$, Canada. The section of mine hosting the bioreactor system is currently undergoing reclamation and was chosen due to its consistent discharge of Se-laden water $\left(0.5 \mathrm{~m}^{3} / \mathrm{s}\right)$ as 
well as its accessibility. Water for the reactor was diverted from the creek outflow of an end-pit lake (Dyno Lake), which exhibits particularly high levels of waterborne Se due to its position in the lower end of the drainage system of the mine. The average Se content of the water flowing out of Dyno Lake is $92.3 \mu \mathrm{g} / \mathrm{L}$. Additional water quality and sediment properties of Dyno Lake are shown in Table 1. Water treatment at this site is further complicated by a sub-arctic climate; below-freezing temperatures and winter snow arrives at the beginning of October.

\section{Bioreactor Design}

The bioreactor system was a simple flow-return design (Fig. 1a), wherein water was diverted from the outflow of Dyno Lake, treated, and then returned to the creek. Specifically, a $15.2 \mathrm{~cm}\left(6^{\prime \prime}\right)$ diameter PVC pipe diverted water from the creek into a 1,022 L (270 gal) plastic sump tank. The creek end of this pipe was placed facing upstream and parallel to the creek flow for maximum collection efficiency. The sump functioned to buffer irregular discharge from the creek and thereby maintained a constant flow into the two bioreactors. The bioreactors were connected to the sump, in parallel, by $2.5 \mathrm{~cm}\left(1^{\prime \prime}\right)$ diameter plastic pipes while a T-junction in these pipes connected two $6.4 \mathrm{~mm}$ (1/ $4^{\prime \prime}$ ) diameter ethylene glycol feeds (clear plastic tubing) from a $341 \mathrm{~L}$ (90 gal) storage tank. The storage tank was elevated on a wooden platform, approximately $45.7 \mathrm{~cm}$ $\left(18^{\prime \prime}\right)$ off the ground, to ensure flow of the viscous ethylene glycol (Univar, Edmonton, AB, Canada) addition to the creek water before it reached the reactors. Ethylene glycol was added to each reactor for two reasons. Primarily, ethylene glycol was considered to be an additional carbon

Table 1 Selected sediment and water quality metrics of Dyno Lake, the source of the bacterial inoculum and the Se-laden mine water treated in the bioreactor system

\begin{tabular}{lll}
\hline & Parameters & Value \\
\hline Water & Total Se & $92.3 \mu \mathrm{g} / \mathrm{L}$ \\
& Dissolved sulfur & $762 \mathrm{mg} / \mathrm{L}$ \\
& Total phosphorus & $3 \mu \mathrm{g} / \mathrm{L}$ \\
& TKN & $0.15 \mathrm{mg} / \mathrm{L}$ \\
& DOC & $1 \mathrm{mg} / \mathrm{L}$ \\
Sediment & pH & 7.65 \\
& Total Se & $8.95 \mu \mathrm{g} / \mathrm{g}$ \\
& Total iron & $21.3 \mathrm{mg} / \mathrm{g}$ \\
& TIC & $2 \%$ \\
& TOC & $6.5 \%$ \\
TC & $8.5 \%$ \\
\hline
\end{tabular}

TIC, TOC, and TC were calculated as percent total of dried sediment $T K N$ total Kjeldahl nitrogen, $D O C$ dissolved organic carbon, TIC total inorganic carbon, TOC total organic carbon, TC total carbon source for the bacteria, and second, ethylene glycol is a non-toxic antifreeze product, which had the potential to maintain the operations of the reactor in below-freezing temperatures. Ethylene glycol was added as $0.1 \%$ of the creek water volume ( $\mathrm{vol} / \mathrm{vol})$ and was regulated by a needle valve at the source tank. The use of ethylene glycol, however, was found to be of minimal impact and necessity during the experiment and was discontinued early on. A photo of the bioreactor system in field operation can be seen in Fig. 1b.

The bioreactors (Fig. 1c) were wooden boxes measuring $5 \mathrm{~m}$ long by $1 \mathrm{~m}$ wide by $1 \mathrm{~m}$ high $\left(16.4^{\prime} \times 3.3^{\prime} \times 3.3^{\prime}\right)$ and containing an active substrate mixture. The bioreactors were placed into the ground so that the top edge of the reactors was at ground level. The bioreactors were lined with waterproof HDPE tarp of $3.2 \mathrm{~mm}\left(1 / 8^{\prime \prime}\right)$ thickness, which was secured to the top edge with nails. This design used the ground to support the contents of the reactors, thereby minimizing material costs. To create a diffuser, a T-junction connected another piece of $2.5 \mathrm{~cm}\left(1^{\prime \prime}\right)$ diameter pipe, which was the width of the reactor chamber, to the end of the inflow pipe from the sump. This pipe was placed just above the bottom of the reactor and four $6.4 \mathrm{~mm}\left(1 / 4^{\prime \prime}\right)$ diameter holes (outlets) were drilled equidistant from the T-junction. A gravel anchor covered the diffuser in the first quarter of the reactor and the gravel was held in place by a heavy screen. This screen and gravel baffle assembly served to protect the contents of the main compartment of the reactor from washouts. The main compartment of each reactor was filled with an active substrate composed of a mixture of mulch (carbon source), manure (nitrogen source and a secondary carbon source), washed gravel (bacterial growth surface), limestone ( $\mathrm{pH}$ buffer), and bone meal (phosphorus source), as well as the bacterial inoculum (Table 2). The active substrate differed slightly in the proportion of mulch and manure between the two reactors (Table 2). The inoculum added to each bioreactor was sediment (soft mud) collected from a shallow wetland at one end of Dyno Lake. The organic, anaerobic nature of the sediment, and the high sulfur content of the water (Table 1) suggested a community of sulfur reducing, anaerobic bacteria was present in Dyno's sediment, later confirmed by microbiological testing (personal communication, A. Sobolewski). The bioreactor's active ingredients were well mixed using a small skid-steer loader prior to filling each reactor. A flap of the tarp liner was used to cover the top of the bioreactors. Water flow through the bioreactors was maintained by gravity at a slope of approximately $2 \%$ (Fig. 1b). A ditch collected discharge from the reactor outflows [two short pieces of $11.4 \mathrm{~cm}\left(4.5^{\prime \prime}\right)$ diameter pipe placed near the top of the downstream end of each reactor], and directed the treated water back into the creek. The retention time in the reactor chambers was varied by 
Fig. 1 The bioreactor system and components. a Components of the bioreactor system, $\mathbf{b}$ field photo of the bioreactor system, c detailed schematic of one bioreactor and its parts (see "Methods" for measurement equivalents)

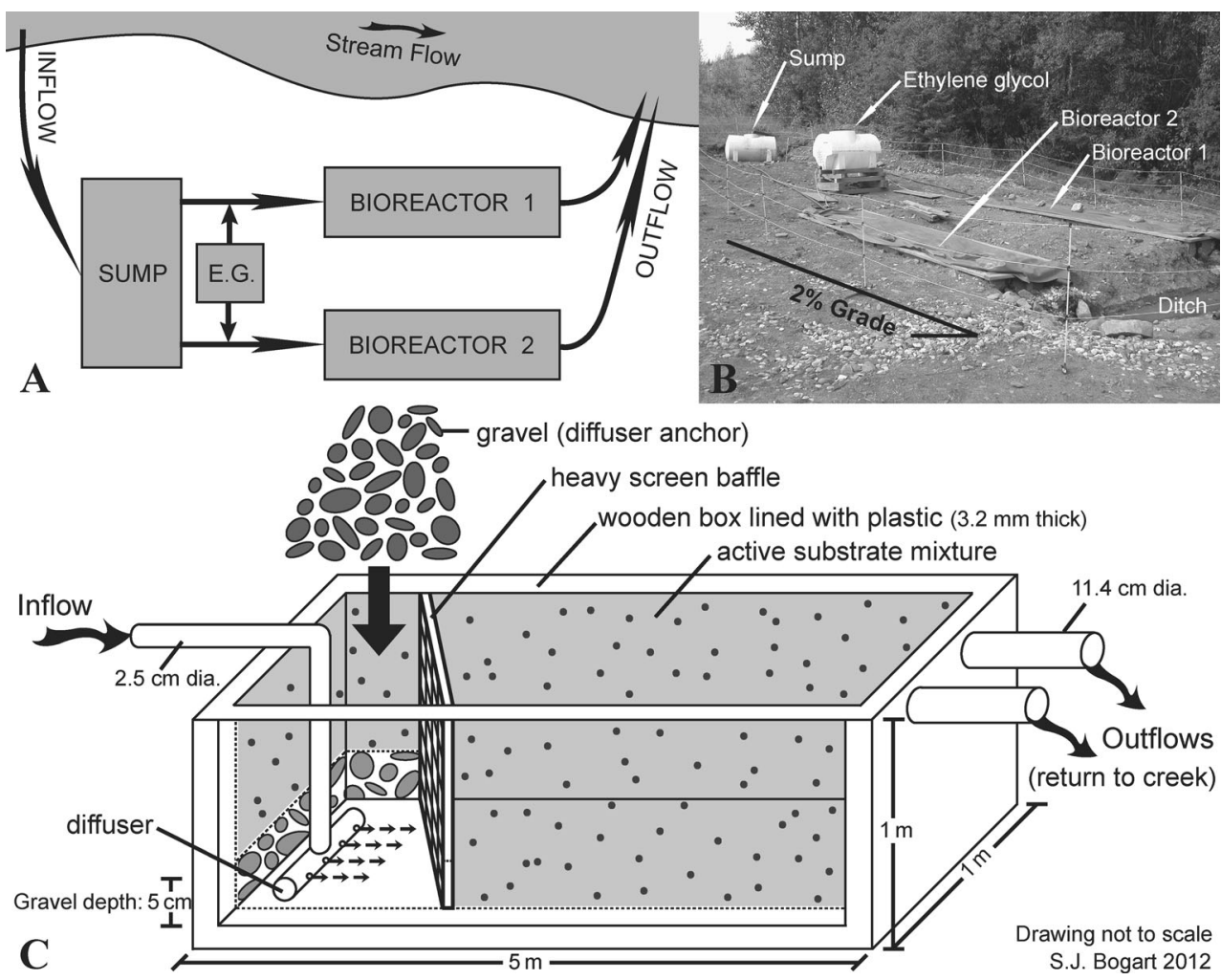

Table 2 Amounts of solid ingredients combined to make the active substrate (percent total volume of substrate) and inoculum within each bioreactor

\begin{tabular}{lll}
\hline Ingredients & Bioreactor 1 & Bioreactor 2 \\
\hline Active substrate & & \\
Mulch & $40 \%$ & $57 \%$ \\
Manure & $32 \%$ & $15 \%$ \\
Gravel & $24 \%$ & $24 \%$ \\
Limestone & $2.7 \%$ & $2.7 \%$ \\
Bone meal & $1.3 \%$ & $1.3 \%$ \\
Bacterial source & & \\
Inoculum $^{\mathrm{a}}$ & $4.5 \mathrm{~L}$ & $4.5 \mathrm{~L}$ \\
\hline
\end{tabular}

a Sediment from Dyno Lake

manipulating inflow rates through gate valves and was set to $\approx 48 \mathrm{~h}$.

Monitoring and Analysis

The performance of the bioreactor system was monitored weekly from August to November 2008. Water samples were taken from the inflow and from the outflows of each bioreactor on a weekly basis for 10 weeks post start-up. Field measurements were taken for $\mathrm{pH}$, temperature, conductivity, and dissolved oxygen (DO). Water samples were preserved in the field and submitted to a certified laboratory (ALS Environment, Edmonton, AB, Canada) for analysis within $48 \mathrm{~h}$. Water was analyzed for nutrients (i.e. total phosphorus, total Kjeldahl nitrogen (TKN), dissolved nitrate/nitrite (combined), and dissolved sulphate) using ion chromatography. Total Se concentration was analyzed by inductively coupled plasma mass spectroscopy. Biological parameters measured were biological oxygen demand (BOD), dissolved organic carbon (DOC), and abundance of Escherichia coli and fecal coliform bacteria.

Data were analyzed using $\mathrm{R}$, an open-source, statistical software ( $\mathrm{R}$ Core Team 2012) and plotted using the $\mathrm{R}$ visualization package, ggplot2 (Wickham 2009). For all tests, statistical significance was accepted at $p \leq 0.05$. Hereon, for simplicity, the outflows of Bioreactors 1 and 2 shall be referred to as Outflows 1 and 2, respectively.

\section{Results}

\section{Reactor Performance}

Water quality underwent distinct visible changes in the first few days of operation of the bioreactor system. For the first day of operation, the outflow of both bioreactors was a turbid, muddy brown color as a result of fine sediment and organic matter washing out of the active substrate. After this time, the discharged water was a clear, slightly yellowbrown color. With a retention time of $48 \mathrm{~h}$, the mean flow 
Fig. 2 Change in total Se, dissolved nitrate/nitrite, and dissolved sulphate concentrations of untreated (inflow) and bioreactor treated (Outflow 1 and 2) mine water throughout the 2008 pilot program

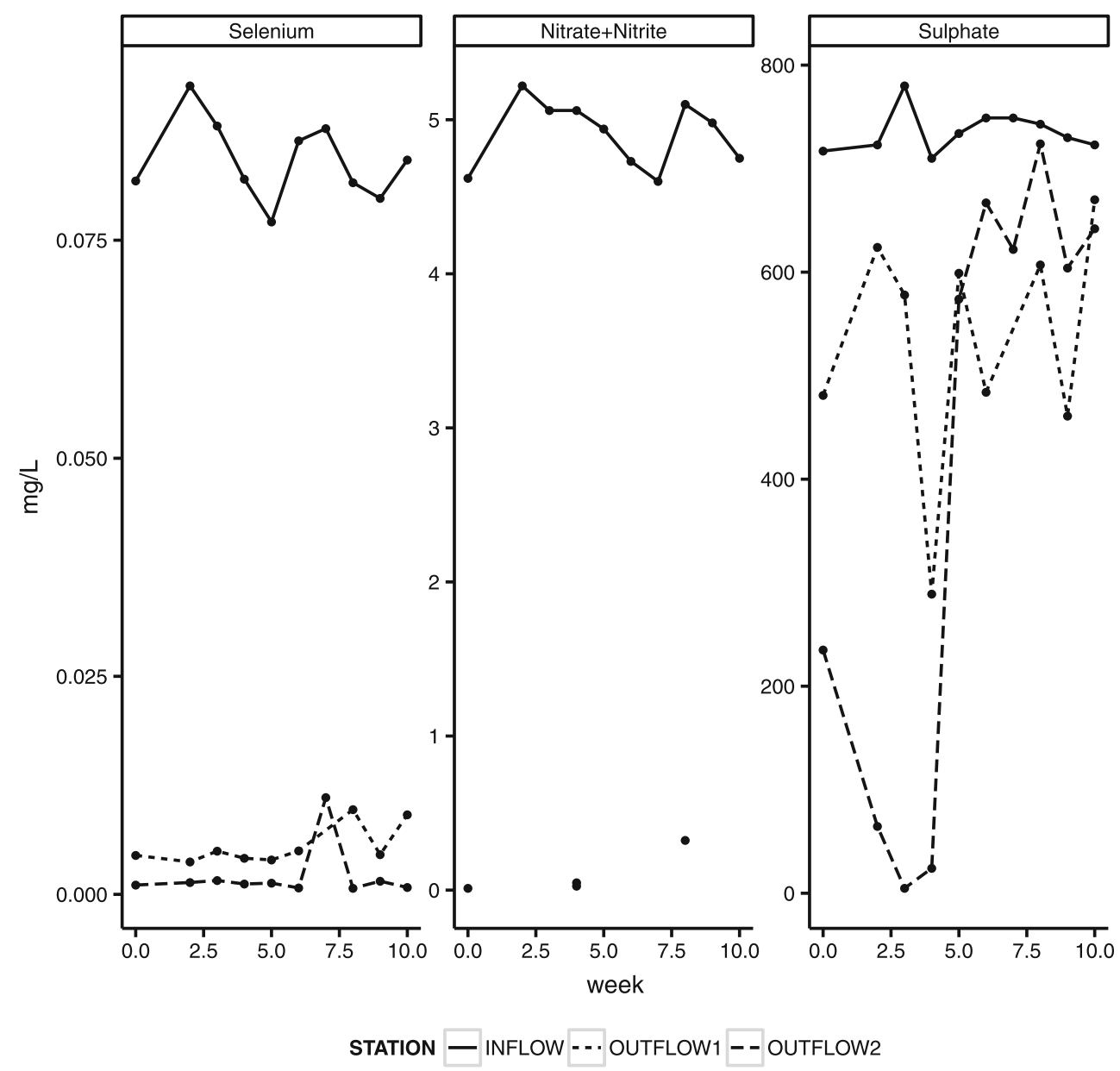

per reactor was approximately $94 \mathrm{~L} / \mathrm{h}$. This meant that the total volume of water treated was 2,250 L/day or $157,500 \mathrm{~L}$ for the duration of the 10 week pilot program and a projected $819,000 \mathrm{~L}\left(819 \mathrm{~m}^{3}\right) /$ year.

\section{Changes in Water Chemistry}

The bioreactor system reduced Se, nitrate/nitrite, and some sulfate in the creek water. The average Se concentration in the inflow water was reduced by $>95 \%$. The inflow into the reactor system had an average Se concentration of $84.5 \mu \mathrm{g} / \mathrm{L}(\mathrm{SE}=1.46)$, while the outflows contained an average of $5.52 \mu \mathrm{g} / \mathrm{L}$ (Outflow $1, \mathrm{SE}=0.75$ ) and $2.13 \mu \mathrm{g}$ / $\mathrm{L}$ (Outflow 2, SE = 1.00) of total Se (Fig. 2). A repeatedmeasures ANOVA was used to compare Se concentrations of the inflow and outflows over time $\left(\mathrm{F}_{2,25}=1,647\right.$; $p<0.0001)$. A Tukey's HSD test revealed that total Se concentrations were significantly different between the inflow and both outflows (Inflow and Outflow 1: $p<0.001$; Inflow and Outflow 2: $p<0.001$ ); however, there was no significant difference between the Se concentrations of the two outflows (Outflow 1 and Outflow 2: $p=0.112$ ). As with Se, nitrate/nitrite levels were strongly reduced in the bioreactors. Nitrate/nitrite concentrations in the inflow water was around $5 \mathrm{mg} / \mathrm{L}$ but was reduced to close to, and often below, detection limits $(<0.01 \mathrm{mg} / \mathrm{L})$ in both outflows (Fig. 2). Dissolved sulfate levels (Fig. 2), however, fluctuated during the experiment but overall, sulfate levels in the inflow were always significantly higher than those of the outflows (repeated-measures ANOVA $\mathrm{F}_{2,25}=9.292 ; p<0.001$; Tukey HSD: Inflow and Outflow 1: $p=0.063$; Inflow and Outflow 2: $p=0.002$ ). Sulfate was not reduced to the same magnitude as Se or nitrate/ nitrite. Although ambient water temperature declined over the 10 week program, from $\approx 14{ }^{\circ} \mathrm{C}$ down to $2{ }^{\circ} \mathrm{C}$ (Fig. 3), temperature did not affect $\mathrm{Se}$ reduction (regression, Outflow $1: \mathrm{R}^{2}=0.26, p=0.155$; Outflow $2: \mathrm{R}^{2}=0.04$, $p=0.623$ ).

Field measurements of $\mathrm{pH}$ and conductivity did not show any changes over the course of the experiment. Median $\mathrm{pH}$ values of the water at the inflow, Outflow 1, and Outflow 2 were 8.29 (range 8.14-8.39), 6.95 (range 5.89-7.40), and 7.30 (range 6.69-7.57), respectively. Water flowing out of the two bioreactors, was significantly 


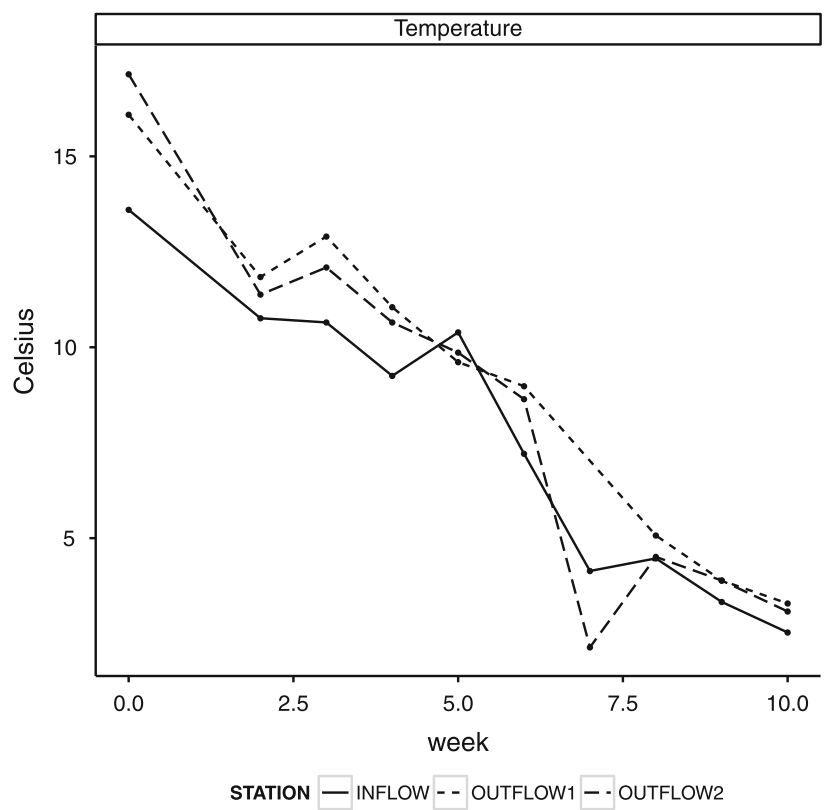

Fig. 3 Water temperature over the course of the monitoring period

more acidic than inflowing water (repeated-measures ANOVA: $\mathrm{F}_{2,25}=102.2 ; p<0.0001$; Tukey HSD: Inflow and Outflow 1: $p<0.0001$; Inflow and Outflow 2: $p<0.0001)$. Conductivity of the inflow water remained constant at $1,997.7 \mu \mathrm{S} / \mathrm{cm}(\mathrm{SE}=22.93)$ throughout the experiment and conductivity of both outflows was the same as the inflow (Outflow 1: 2,393.2 $\mu \mathrm{S} / \mathrm{cm}, \mathrm{SE}=247.09$; Outflow 2: 1,945.0 $\mu \mathrm{S} / \mathrm{cm}, \mathrm{SE}=61.26$ ).

DO concentrations exhibited some variation in the inflow and outflows (Fig. 4). Generally in the outflows, DO was near $3 \mathrm{mg} / \mathrm{L}$ in the first 5 weeks, after which it was around $9 \mathrm{mg} / \mathrm{L}$. DO levels were always lower in the outflows than in the inflow. DO levels at the outflow might be overestimated due to sampling of the outflow water after it surfaces out of the reactor, giving it a chance to mix with atmospheric oxygen again.

Dissolved phosphorus and TKN shared similar trends over time. Phosphorus and TKN levels declined during the course of the experiment but were always higher in both outflows than in the inflow (Fig. 5).

Biological parameters generally decreased over time but showed a similar pattern of being always higher in the outflows compared to the inflow of the bioreactors. BOD was generally below detection limit at the inflow $(<1 \mathrm{mg} /$ $\mathrm{L}$ ), while bacterial growth in the reactor elevated oxygen demand at the outflow considerably (Fig. 6). DOC in both outflows was around three orders of magnitude higher than in the inflow at the beginning of the experiment and declined to around one order of magnitude higher at the end of the experiment (Fig. 6). Bacteria concentrations in the water were highly elevated in the outflows of both

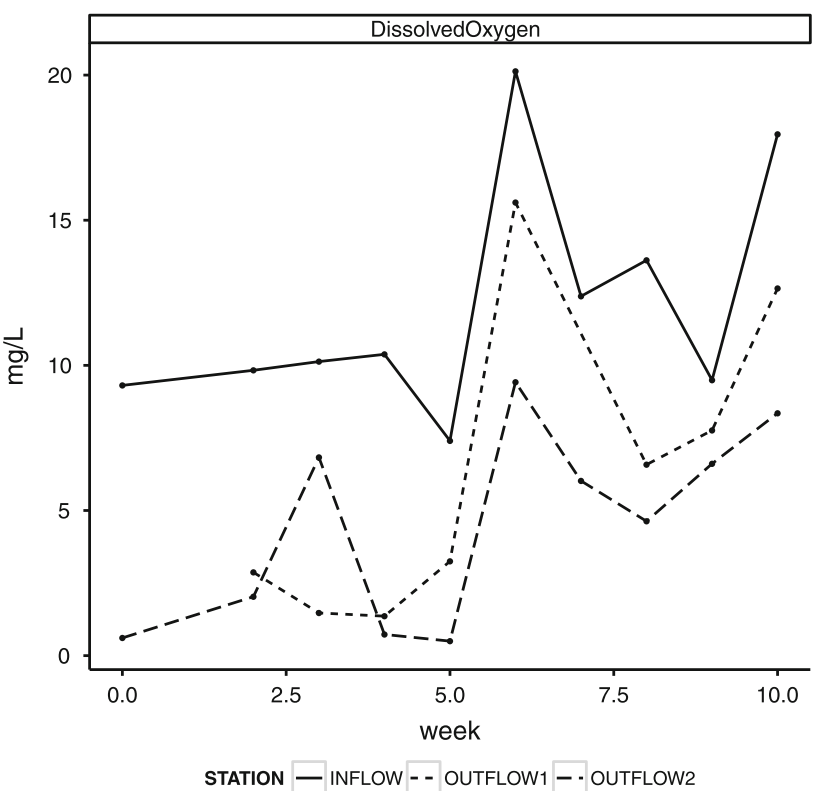

Fig. 4 Dissolved oxygen over the monitoring period

bioreactors. While amounts of E. coli and fecal coliform bacteria in the inflow were close to detection limits, their concentration was three to four orders of magnitude higher in both outflows (Fig. 7).

\section{Operating Costs}

The total cost for constructing and operating the bioreactor system over the 10 week trial period was $\$ 45,000$. The material cost was $\$ 4,500$, including hardware to construct the bioreactor system $(\$ 1,500)$, the ingredient mixture $(\$ 1,100)$, and the ethylene glycol, which was discontinued ( $\$ 1,900$ for $341 \mathrm{~L}$ or $90 \mathrm{gal})$. The rest of the costs went to a consulting company to oversee the initial setup of the reactor, a construction company that was hired to build the bioreactor system according to our design, and equipment rental fees (e.g. the skid-steer loader).

\section{Discussion}

\section{Bioreactor Efficiency}

The bioreactor system was very successful in eliminating Se from Dyno Lake mine effluent. It achieved a $94 \%$ (Outflow 1) and $98 \%$ (Outflow 2) reduction. Se reduction in both bioreactors happened in an environment where sulfate was present in amounts four to five orders of magnitude higher than Se concentrations, showing a strong bacterial preference for Se as an energy source as compared to sulfate (Lenz et al. 2008; Zhang and 


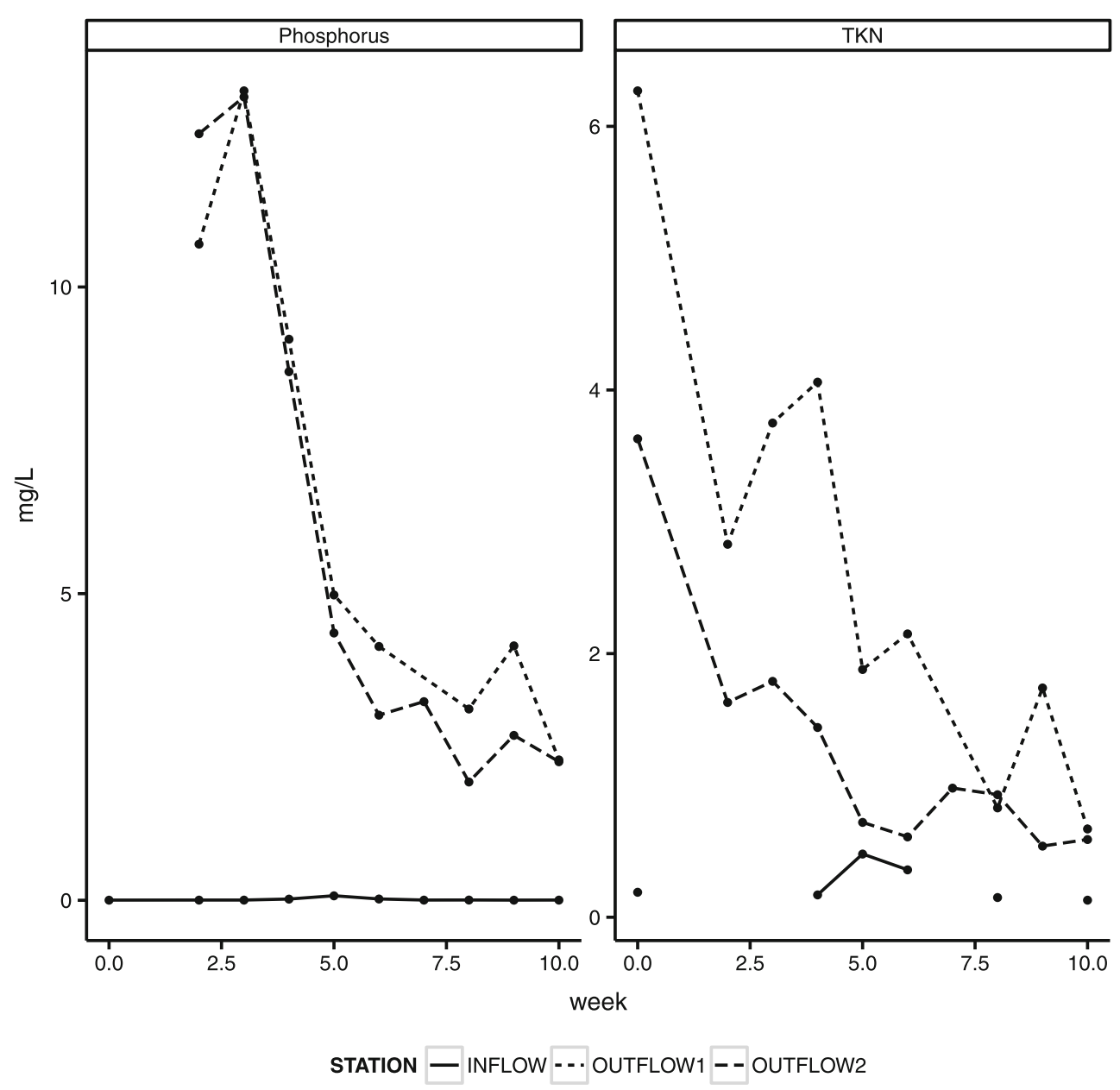

Fig. 5 Total phosphorus concentration and TKN (biologically available nitrogen), in untreated and bioreactor treated water during the experiment. Missing values for the inflow were below detection limits

Frankenberger 2003). The simultaneous reduction of Se oxyanions and nitrate/nitrites suggests potential competition between these substrates during the reduction process, as it was previously determined that nitrate reduction precedes selenite reduction (Steinberg et al. 1992). However, additional evidence (reviewed in Macy et al. 1993), has shown that the terminal reductases used to reduce selenate and nitrate are different. Moreover, nitrite reductase is used by some bacteria, e.g. Thaurea selenatis, to catalyze the reduction of selenate to selenite, indicating that the presence of nitrite is required before selenate can be reduced. Oremland and Blum (1999) determined that the reduction of Se oxyanions and nitrate/nitrites in other bacteria is poorly understood but is likely dependent on more processes than is controlled by only one or two enzymes. As we did not identify the bacterial species responsible for $\mathrm{Se}$ reduction in our study, we supplied manure as a nitrogen source. However, the reduction of nitrate/nitrites did not affect the reduction of $\mathrm{Se}$ in either of the bioreactors (Fig. 2). Moreover, the observed Se removal efficiency of the bioreactors was comparable to previous pilot studies of similar size (Cantafio et al. 1996; Lenz et al. 2008) and a lab-bench study (Fujita et al. 2002), while it performed more efficiently than a large scale field test of a biochemical reactor pit, a related technology (Golder Associates 2010).

\section{Physico-Chemical Changes in the Reactor}

While previous studies have used known bacteria grown in controlled laboratory settings as inoculants (Hunter and Kuykendall 2007; Ikram and Faisal 2010), we obtained our bacterial inoculant from the organic sediment of the same water body from which we treated effluent. In doing so, we have shown that the anaerobic portion of the sediment in a water body rich in Se and sulfur can host a bacterial community capable of reducing sulfur and Se oxyanions. The bacteria were very effective at removing Se from the mine water and are likely well adapted to the local environment and water chemistry. Our results support the use 


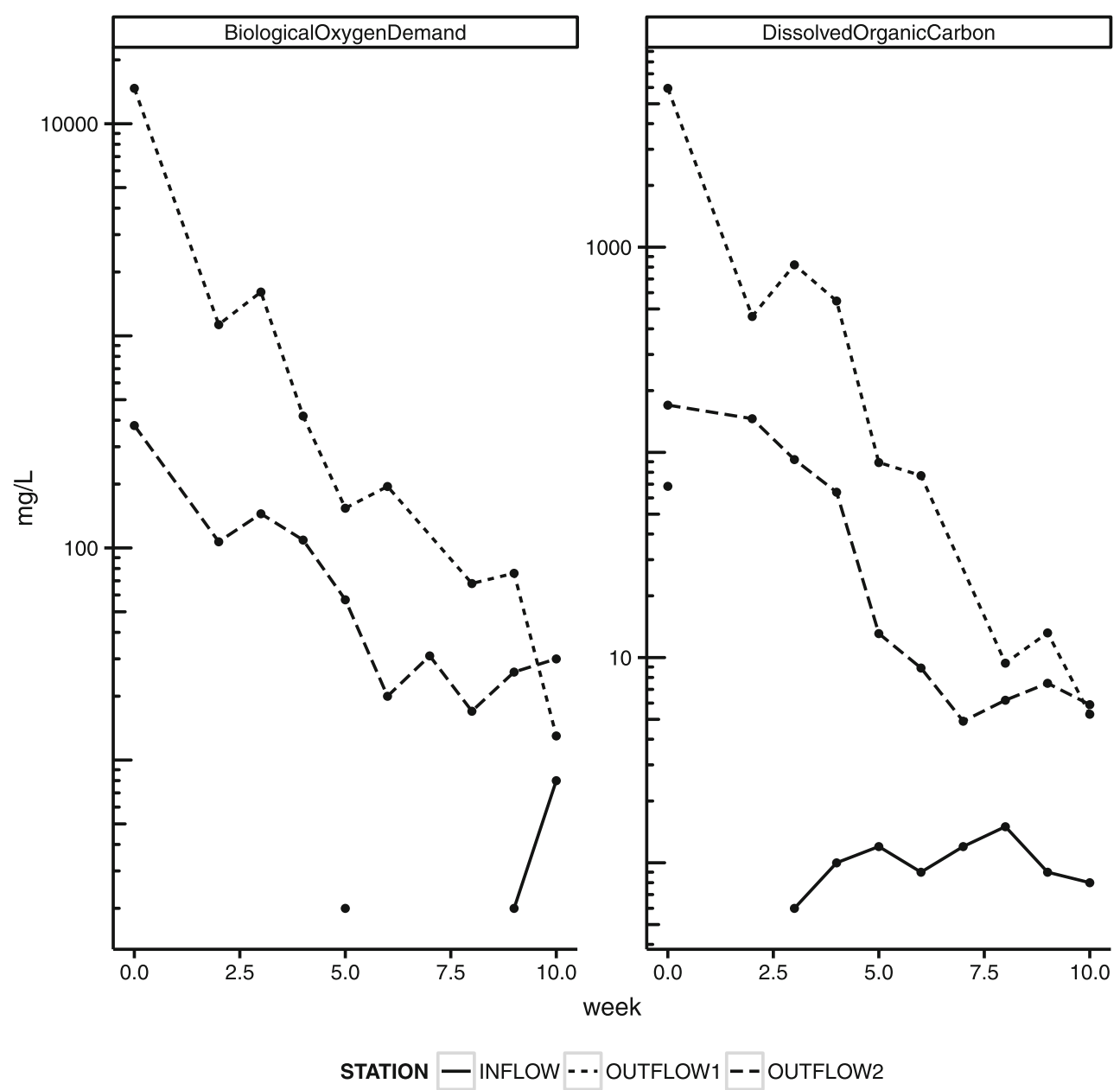

Fig. 6 Biological oxygen demand (BOD) and dissolved organic carbon (DOC) in untreated and bioreactor treated water during the pilot program. Missing values for the inflow were below detection limits

of local bacterial communities present in Se-affected areas for use in treatment.

The observed Se reduction process in our bioreactors was the result of reducing Se oxyanions to elemental Se, a precipitate, which was then deposited within the reactors' active substrate. If the bioreactor system ran longer than in this experiment, an additional stage, such as a flocculation barrier, may have to be added in which elemental Se could be caught after periodically flushing the bioreactors (Cantafio et al. 1996). Long-term operation of the reactor requires replacing the substrate periodically, drying and processing the removed substrate to remove remaining organic matter and concentrate the precipitated Se. The concentrate can then be taken out of the environment for final deposition or the Se could be extracted and recycled for industrial use.

Lenz et al. (2008) showed that bioreactors work under controlled temperature conditions in warmer climates, but our experiment shows that Se-reducing bacteria, present in the local environment, can be used to reduce Se oxyanions under field conditions in a sub-arctic environment. Se removal remained constant even though the inflow water temperature declined from 17 to $2{ }^{\circ} \mathrm{C}$ at the end of the experiment. Our results agree with those of a related technology, tested in a different part of the Alberta Rockies which experienced similarly low temperatures (Golder Associates 2010). In general, the temperature within the bioreactors will be slightly warmer than the surrounding environment, due to the in-ground construction. This kept the bioreactors working in sub-freezing ambient temperatures and assures that inflowing water would freeze before the reactor, thereby providing continuous water treatment. We conclude that as long as the mine water is not frozen, it can be treated effectively at near-freezing temperatures with no significant effect on Se removal rates.

DO readings were lower in the reactor effluent than in the inflow; however, outflow measurements never reached anoxic conditions. This is attributed to water turbulence 


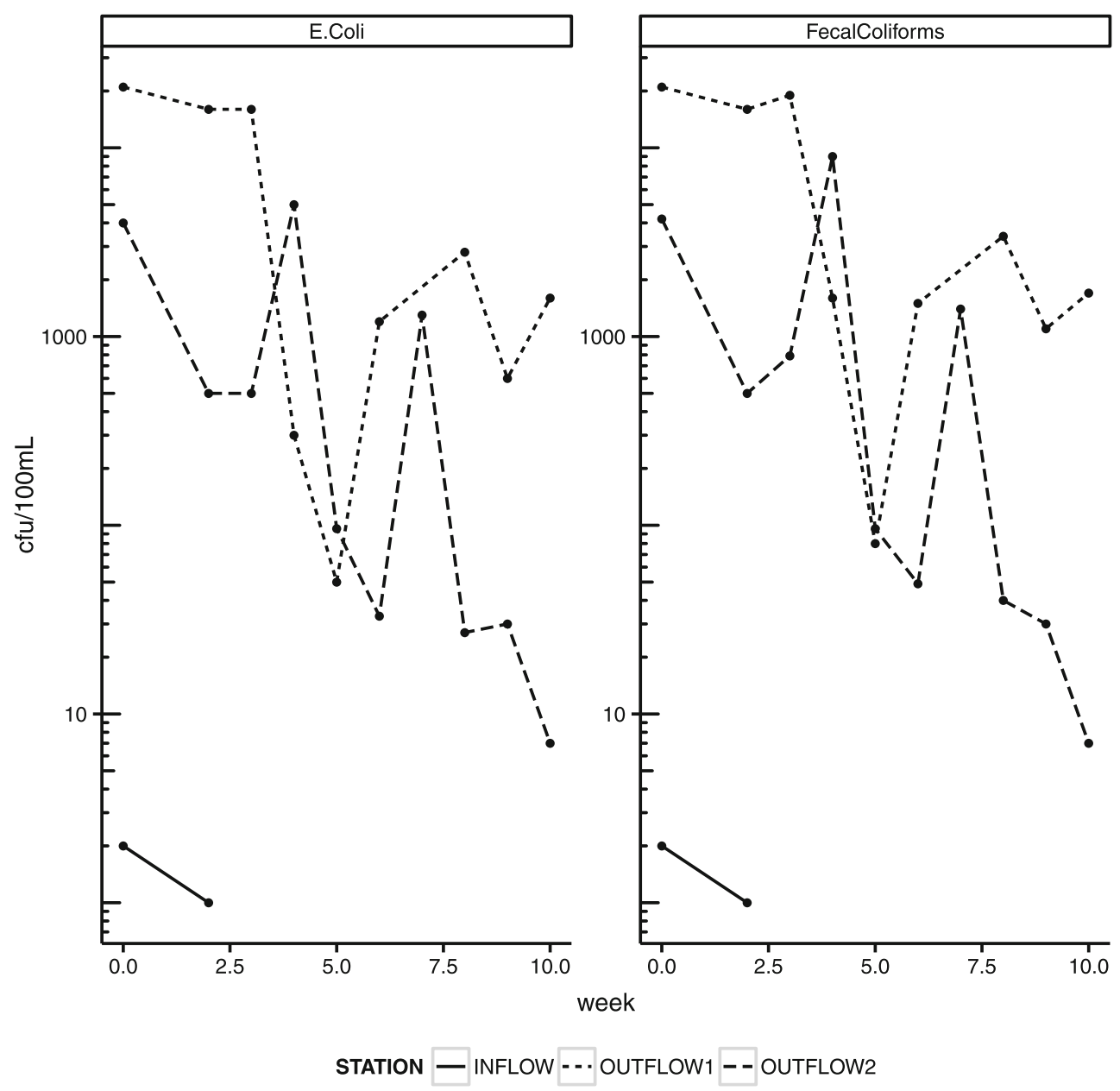

Fig. 7 Concentrations of E. coli and fecal coliform bacteria in water for the duration of the experiment. Missing values for the inflow was below detection limits

right after the water exited the reactor, i.e. the point of measurement, where immediate mixing with air enriched DO in the water. Although a confounding point from a research perspective, it is a sign that treated water rejoining the creek will not be oxygen deprived at the point of discharge into the ecosystem.

Conductivity remained fairly unchanged when passing through the reactor, while sulfates and nitrates were removed. The likely reason for the unchanged conductivity is the high calcium carbonate content in the water, which remained in the water after passing through the reactor.

\section{Environmental Challenges of the Design}

There were several metrics of potential environmental concern related to the bioreactors, i.e. E. coli, fecal coliforms, BOD, DOC, TKN, and total phosphorus, which were at high concentrations in the outflows while not present in the inflow water, or present in very low concentrations. E. coli accounted for nearly all of the fecal coliform bacteria (Fig. 7). The source of the E. coli, which is restricted to human or animal feces (Health Canada 2006), was the manure used in the bioreactor. The presence of these bacteria in a potential drinking water source is not tolerable (Health Canada 2006). Cell counts declined over time and were mostly under the water quality guidelines [100 cells $/ 100 \mathrm{~mL}$ for $E$. coli and 1,000 cells $/ 100 \mathrm{~mL}$ for fecal coliforms (Alberta Environment 1999, 2000)] after the first 5 weeks of operation. The increase in bacterial abundance in the outflow resulted in a significantly higher BOD for much of the pilot program. While above guideline values in the beginning of the experiments, BOD fell below the required maximum of $100 \mathrm{mg} / \mathrm{L}$ after the first 5 weeks of operation (Alberta Environment 1999, 2000). The outflows also showed increases in DOC, TKN, and total phosphorus compared to the inflow. These changes were all due to the choice of active substrate ingredients for the reactor, i.e. the manure and mulch. Alternative carbon and nitrogen sources need to be found in order to reduce risks of $E$. coli contamination and eutrophication of downstream 
systems. In addition to mulch and manure, possible alternative carbon sources are synthetically derived ones such as acetate (Macy et al. 1993), or natural by-products of the food industry including molasses (Cantafio et al. 1996), lactate (Hockin and Gadd 2006; Lenz et al. 2008), or whey (Koschorreck et al. 2011). These carbon sources would allow for more stoichiometric dose control; however, especially in remote settings, these more refined ingredients would increase treatment costs substantially. Less processed, potential carbon sources that are more readily available and are cheaper, include old hay or leaf litter, which could be obtained from local farmers or municipal waste collection, as well as cleared vegetation from overburden on the mine-site (Kumar et al. 2011). The manure, which is a nitrogen source as well as a carbon source, should be replaced by an alternative with adequate nitrogen content. Commercial liquid fertilizers would be an easy way to add a nitrogen source, but again, would have a higher cost than waste products. In our opinion, the best nitrogen source is manure and agricultural waste, but a treatment to limit $E$. coli contamination, i.e. pasteurizing and drying of the manure is necessary prior to use. Finally, it is important to note that although the above biological and nutrient parameters were still higher in the outflows than the inflow, and while some exceeded environmental limits even at the end of the pilot program, the data trends indicate that these parameters would be likely have all been within acceptable limits after a few more weeks of monitoring.

\section{Large-Scale Applications}

Our results show that simpler designed reactors work in small field settings, but the treatable volume needs to increase drastically to address rising Se discharge volumes (Dessouki and Ryan 2010). Our pilot-sized bioreactor system treated mine water at a rate of $0.2 \mathrm{~m}^{3} / \mathrm{h}$; however, a full-scale system would need to treat a minimum discharge flow of $0.5 \mathrm{~m}^{3} / \mathrm{s}$, or $1,800 \mathrm{~m}^{3} / \mathrm{h}$, to treat Dyno Lake's average discharge. However, this endpit lake is only one of many effluent sources at this mine site. While scaling up the size of the bioreactor system appears to be a logical step, we estimate that the size needed to achieve successful treatment of present $\mathrm{Se}$ concentrations (Table 1) and discharge volumes between 0.5 and $1 \mathrm{~m}^{3} / \mathrm{s}$, reactors the size of a small end-pit lake would be needed.

Since most discharges, especially from mine sites, flow out of end-pit lakes or settling ponds, we suggest using these water bodies themselves as in situ bioreactors. Organic content in the lake can be increased significantly by adding plant waste products (e.g. woodchips, hay, leaf litter, compost, municipal sewage, agricultural waste), to provide carbon and nitrogen sources for the sulfur/Se reducing bacteria (McCullough and Lund 2011). We have shown that the desired Se reducing bacteria are already present in an end-pit lake laden with Se. Supplementary addition of phosphorus and/or nitrogen through fertilization (dependent on ambient ratios and concentrations) can induce a strong phytoplankton bloom (Schindler 1980), which will reduce DO in the hypolimnion, thereby creating an anoxic environment for the bacterial community. Variation in water levels and discharge volumes, which were addressed through reservoir tanks in the small-scale experiment, require special consideration during the design of a large treatment facility. Fluctuations in the water table would not be too much of a concern, as long as anaerobic conditions within the pit do not get disturbed. Provided the treatment pit is situated at the bottom of the watershed, management of the inflowing water sources upstream can dampen extreme events and ensure continuous successful Se treatment.

We suggest that using end-pit lakes as in situ bioreactors would be the next step in cost efficiency and that this approach would require even less effort than constructing ground-level bioreactors next to lake outflows. While in situ remediation of end-pit lakes has already been tried for acid mine drainage (AMD) lakes (Koschorreck et al. 2011; Lessmann et al. 2003), our results suggest that nonacidic lakes are even more suitable for this approach and should be further investigated.

\section{Conclusions}

In our model approach, we applied the general mechanisms of anaerobic bioreactors in the cheapest way possible, together with locally available resources. In our pilot-scale project, we showed effective Se reduction in the field, reducing the concentration of $\mathrm{Se}$ in non-acidic mine water by $95 \%$, even at a water temperature of $2{ }^{\circ} \mathrm{C}$. We highlighted three major factors required for successful $\mathrm{Se}$ removal: an aquatic anoxic environment, organic matter providing a carbon and nitrogen source as a bacterial substrate, and sulfur/Se reducing bacteria. Moreover, we showed that those three prerequisites can be met while keeping overall costs low. By assessing the local environment, a field source of Se-reducing bacteria can be collected for use without expensive microbiological testing, laboratory rearing, or purchasing of a commercial inoculant. The overall costs of construction and maintenance of the reactor remained comparatively low by using easily accessible organic substrate manure as well as integrating simple building materials into the landscape. The results are promising for larger-scale applications and the use of existing industrial structures, such as settling ponds or 
small end-pit lakes, can make increases in scale feasible and integration into mine remediation processes possible.

Acknowledgments The authors thank the University of Lethbridge, Lethbridge, AB, the Atomic Energy of Canada Limited (AECL), Chalk River, ON, and Alberta Environment, Edmonton, $A B$, for funding the project. Thanks to Grande Cache Coal for their on-site support, and to field crews from Microbial Technologies Inc., Gibsons, BC, and Crater Enterprises, Grande Cache, AB, for the contracted construction, maintenance, and photo of the reactor. Thanks to Sarah Bogart for the technical drawing of the reactor and for comments on reviewing the manuscript.

Open Access This article is distributed under the terms of the Creative Commons Attribution License which permits any use, distribution, and reproduction in any medium, provided the original author(s) and the source are credited.

\section{References}

Alberta Environment (1999) Surface water quality guidelines for use in Alberta. Environ Sci Div, Environ Services, Edmonton

Alberta Environment (2000) Guidelines for municipal wastewater irrigation. Municipal Program Dev Branch, Environ Sci Div, Environ Services, Edmonton

Alberta Environment (2006) Evaluation of treatment options to reduce water-borne selenium at coal mines in west-central Alberta. Environ Sci Div, Environ Services, Edmonton, pp 1-45

Banuelos G, Lin Z, Wu L, Terry N (2002) Phytoremediation of selenium-contaminated soils and waters: fundamentals and future prospects. Rev Environ Health 17:291-306

Berken A, Mulholland MM, Leduc DL, Terry N (2002) Genetic engineering of plants to enhance selenium phytoremediation. CRC Crit Rev Plant Sci 21:37-41

Cantafio AW, Hagen KD, Lewis GE, Bledsoe TL, Nunan KM, Macy J (1996) Pilot-scale selenium bioremediation of San Joaquin drainage water with Thauera selenatis. Appl Environ Microbiol 62:3298-3303

Conley JM, Funk DH, Buchwalter DB (2009) Selenium bioaccumulation and maternal transfer in the mayfly Centroptilum triangulifer in a life-cycle, periphyton-biofilm trophic assay. Environ Sci Technol 43:7952-7957. doi:10.1021/es9016377

Debruyn AMH, Chapman PM (2007) Selenium toxicity to invertebrates: will proposed thresholds for toxicity to fish and birds also protect their prey? Environ Sci Technol 41:1766-1770

Deforest DK, Gilron G, Armstrong SA, Robertson EL (2011) Species sensitivity distribution (SSD) evaluation for selenium in fish eggs: considerations for development of a Canadian tissue-based guideline. Integr Environ Assess Manag 8:6-12. doi:10.1002/ieam.245

Dessouki TCE, Ryan A (2010) Canada-British Columbia water quality monitoring agreement (water quality assessment of the Kootenay, Elk and St. Mary River). Environment Canada, pp 1-55

Frankenberger WT Jr, Amrhein C, Fan TWM, Flaschi D, Glater J, Kartinen E Jr, Kovak K, Lee E, Ohlendorf HM, Owens L, Terry N, Toto A (2004) Advanced treatment technologies in the remediation of seleniferous drainage waters and sediments. Irrig Drain Syst 18:19-42

Fujita M, Ike M, Kashiwa M, Hashimoto R, Soda S (2002) Laboratory-scale continuous reactor for soluble selenium removal using selenate-reducing bacterium, Bacillus sp. SF-1. Biotechnol Bioeng 80:755-761. doi:10.1002/bit.10425

Golder Associates (2010) Cardinal River operations pilot-scale biochemical reactor testing report. Golder Associates Inc., Lakewood, p 43
Griffith MB, Norton SB, Alexander LC, Pollard AI, LeDuc SD (2012) The effects of mountaintop mines and valley fills on the physicochemical quality of stream ecosystems in the central Appalachians: a review. Sci Total Environ 417-418:1-12. doi:10.1016/j.scitotenv.2011.12.042

Gusek J, Conroy K, Rutkowski T (2008) Past, present and future for treating selenium-impacted water. In: Proceedings of the West Virginia Mine Drainage Task Force, pp 1-15. http://en-us.www. mozilla.com/en-US/firefox/central/

Hamilton SJ (2004) Review of selenium toxicity in the aquatic food chain. Sci Total Environ 326:1-31. doi:10.1016/j.scitotenv.2004. 01.019

Health Canada (2006) Guidelines for Canadian drinking water quality: guideline technical document. Health Canada, Ottawa

Hockin S, Gadd GM (2006) Removal of selenate from sulfatecontaining media by sulfate-reducing bacterial biofilms. Environ Microbiol 8:816-826. doi:10.1111/j.1462-2920.2005.00967.x

Hunter WJ, Kuykendall LD (2007) Reduction of selenite to elemental red selenium by Rhizobium sp. strain B1. Curr Microbiol 55:344-349. doi:10.1007/s00284-007-0202-2

Hunter WJ, Manter DK (2009) Reduction of selenite to elemental red selenium by Pseudomonas sp. strain CA5. Curr Microbiol 58:493-498. doi:10.1007/s00284-009-9358-2

Ikram M, Faisal M (2010) Comparative assessment of selenite (SeIV) detoxification to elemental selenium ( $\mathrm{Se} 0$ ) by Bacillus sp. Biotechnol Lett 32:1255-1259. doi:10.1007/s10529-010-0291-z

Janz DM (2011) Selenium. In: Chris M, Wood APF, Brauner CJ (eds) Homeostasis and toxicology of essential metals, chap 7. Academic Press, New York City, pp 327-374

Kelly JM, Janz DM (2009) Assessment of oxidative stress and histopathology in juvenile northern pike (Esox lucius) inhabiting lakes downstream of a uranium mill. Aquat Toxicol 92:240-249. doi:10.1016/j.aquatox.2009.02.007

Kharaka YK, Ambats G, Presser TS, Davis RA (1996) Removal of selenium from contaminated agricultural drainage water by nanofiltration membranes. Appl Geochem 11:797-802

Koschorreck M, Boehrer B, Friese K, Geller W, Schultz M, WendtPotthoff K (2011) Oxygen depletion induced by adding whey to an enclosure in an acidic mine pit lake. Ecol Eng 37:1983-1989. doi:10.1016/j.ecoleng.2011.08.003

Kumar NR, McCullough CD, Lund MA, Newport M (2011) Sourcing organic materials for pit lake bioremediation in remote mining regions. Mine Water Environ 30:296-301. doi:10.1007/s10230011-0144-6

Lemly AD (1993a) Guidelines for evaluating selenium data from aquatic monitoring and assessment studies. Environ Monit Assess 28:83-100. doi:10.1007/BF00547213

Lemly AD (1993b) Teratogenic effects of selenium in natural populations of freshwater fish. Ecotoxicol Environ Saf 26:181-204

Lemly AD (1997) Ecosystem recovery following selenium contamination in a freshwater reservoir. Ecotoxicol Environ Saf 36:275-281. doi:10.1006/eesa.1996.1515

Lemly AD (2002) Symptoms and implications of selenium toxicity in fish: the Belews Lake case example. Aquat Toxicol 57:39-49

Lenz M, Lens PNL (2009) The essential toxin: the changing perception of selenium in environmental sciences. Sci Total Environ 407:3620-3633. doi:10.1016/j.scitotenv.2008.07.056

Lenz M, Hullebusch EDV, Hommes G, Corvini PF, Lens PN (2008) Selenate removal in methanogenic and sulfate-reducing upflow anaerobic sludge bed reactors. Water Res 42:2184-2194. doi:10. 1016/j.watres.2007.11.031

Lessmann D, Fyson A, Nixdorf B (2003) Experimental eutrophication of a shallow acidic mining lake and effects on the phytoplankton. Hydrobiologia 506-509:753-758. doi:10.1023/B:HYDR. 0000008628.41451.aa 
Macy JM, Lawson S, Demoll-Decker H (1993) Bioremediation of selenium oxyanions in San Joaquin drainage water using Thaurea selenatis in a biological reactor system. Appl Microbiol Biotechnol 40:588-594

McCullough CD, Lund MA (2011) Bioremediation of acidic and metalliferous drainage (AMD) through organic carbon amendment by municipal sewage and green waste. J Environ Manag 92:2419-2426. doi:10.1016/j.jenvman.2011.04.011

Oremland R, Blum J (1999) Simultaneous reduction of nitrate and selenate by cell suspensions of selenium-respiring bacteria. Appl Environ Microbiol 65:4385-4392

Oremland RS, Blum JS, Culbertson CW, Visscher PT, Miller LG, Dowdle P, Strohmaier FE (1994) Isolation, growth, and metabolism of an obligately anaerobic, selenate-respiring bacterium, strain SES-3. Appl Environ Microbiol 60:3011-3019

Orr PL, Guiguer KR, Russel CK (2006) Food chain transfer of selenium in lentic and lotic habitats of a western Canadian watershed. Ecotoxicol Environ Saf 63:175-188. doi:10.1016/j. ecoenv.2005.09.004

R Core Team 2012) R: a language and environment for statistical computing. R Foundation for Statistical Computing, Vienna

Ruhl L, Vengosh A, Dwyer GS, Hsu-Kim H, Schwartz G, Romanski A, Smith DS (2012) The impact of coal combustion residue effluent on water resources: a North Carolina example. Environ Sci Technol 46:12226-12233. doi:10.1021/es303263x

Rutkowski T, Hanson R, Conroy K (2013) Mine water treatment options for meeting stringent selenium regulatory limits. In: Proceedings of the International Mine Water Association, pp 711-716. http://www.imwa.info/docs/imwa_2013/ IMWA2013_Rutkowski_570.pdf

Schindler DW (1980) The effect of fertilization with phosphorus and nitrogen versus phosphorus alone on eutrophication of experimental lakes. Limnol Oceanogr 25:1149-1152. doi:10. 4319/lo.1980.25.6.1149

Steinberg N, Blum J, Hochstein L, Oremland R (1992) Nitrate is a preferred electron acceptor for growth of freshwater selenaterespiring bacteria. Appl Environ Microbiol 58:426-428

Terry N, Sambukumar S, Leduc DL (2003) Biotechnological approaches for enhancing phytoremediation of heavy metals and metalloids. Acta Biotechnol 23:281-288

Thompson A, Parker DR, Amrhein C (2003) Selenate partitioning in field-situated constructed wetland mesocosms. Ecol Eng 20:17-30. doi:10.1016/S0925-8574(02)00145-3

Wickham H (2009) ggplot2: elegant graphics for data analysis, 1st edn. Springer, New York. ISBN: 978-0-387-98140-6

Winkel LHE, Johnson CA, Lenz M, Grundl T, Leupin OX, Amini M, Charlet L (2011) Environmental selenium research: from microscopic processes to global understanding. Environ Sci Technol 46:571-579. doi:10.1021/es203434d

Wu L (2004) Review of 15 years of research on ecotoxicology and remediation of land contaminated by agricultural drainage sediment rich in selenium. Ecotoxicol Environ Saf 57:257-269. doi:10.1016/S0147-6513(03)00064-2

Zhang Y, Frankenberger WT (2003) Factors affecting removal of selenate in agricultural drainage water utilizing rice straw. Sci Total Environ 305:207-216. doi:10.1016/S0048-9697(02)00479-5

Zhang Y, Frankenberger WT (2006) Removal of selenate in river and drainage waters by Citrobacter braakii enhanced with zero-valent iron. J Agric Food Chem 54:152-156. doi:10.1021/jf058124o

Zhang Y, Wang J, Amrhein C, Frankenberger WT (2005) Removal of selenate from water by zerovalent iron. J Environ Qual 34:487-495 